\title{
Cikkismertetés: Svédország stratégiája az antibiotikum- rezisztencia elleni küzdelemben (Egészségügyi és Szociális Minisztérium, Svédország Kormánya)
}

\author{
Article review: Swedish strategy to combat antibiotic resistance \\ (Ministry of Health and Social Affairs, Government of Sweden)
}

Ismertető: $\quad$ Gajdács Márió $\square$

Szegedi Tudományegyetem Általános Orvostudományi Kar, Klinikai Mikrobiológiai Diagnosztikai Intézet

Ismertetett cikk: Swedish strategy to combat antibiotic resistance (Ministry of Health and Social Affairs, Government of Sweden) pp. 1-24.

Beküldve: $\quad$ 2019. 01. 08.

doi: $\quad$ 10.24365/ef.v60i2.398

Kulcsszavak: Svédország; stratégia; antibiotikum-rezisztencia; egészségügy; célok

Keywords: Sweden; strategy; antibiotic resistance; healthcare; goals

Az antibiotikumok használata kapcsolatba hozható mind a bakteriális rezisztencia kialakulásával, mind annak terjedésével. Valódi elkötelezettség és szigorú intézkedések szükségesek az antibiotikum-rezisztencia elleni küzdelemben, ha biztosítani szeretnénk, hogy a jövő nemzedékei számára is elérhetőek legyenek a fertőző betegségek kezelésére szolgáló gyógyszerek. A nemzetközi szintű munka és együttmúködés létfontosságú az emberi és állati fertőzések kezelési lehetőségének megőrzését célzó, nemzeti szintű törekvések eléréséhez. A Világgazdasági Fórum (WEF) nyilatkozatában is szerepel, hogy az antibiotikum-rezisztencia olyan globális probléma, ami szociális helyzettől függetlenül mindenkit érint, és amelynek megoldását egyik nemzet vagy szervezet sem képes önállóan kezelni. A különböző országok kormányainak felelősségét az antibiotikum-rezisztencia elleni harcban megerősítette az Egészségügyi Világszervezet (WHO) által 2015 májusában megfogalmazott Globális cselekvési terv (Global action plan on antimicrobial resistance).
Egyre többen vélik úgy, hogy az antibiotikumokra is úgy kellene tekintenünk, mint más, élethez nélkülözhetetlen alapjogra (pl. élelem, ivóvíz), melyeknek hiányát komolyan kell venni, és amelyhez mindenki számára biztosítani kell a hozzáférést. Ezt az egészségügyi megközelítést nevezik One Health szemléletnek. Fontos, hogy ezt a kifejezést úgy értelmezzük, hogy érintsünk minden jelentős tényezőt a gazdasági oldaltól az oktatáson és kutatáson át a humanitárius tevékenységekig, annak érdekében, hogy rendszerezve és globálisan kezeljük a rezisztencia problémáját.

Svédországban széles körű az egyetértés a politikai szférában az antibiotikum-rezisztencia elleni harc fontosságáról. Felismerték, hogy a nozokomiális fertőzések megelőzésének előfeltétele az antibiotikumok felelős használata, a fertőzések megelőzése és az egészségügyi szakemberek magas tudásszintjének fenntartása. A svéd állami berendezkedésben az egészségügyi ellátás biztosítása és finanszírozása 
decentralizált, és a 21 megyei önkormányzat felelősségét képezi. Régi időkre visszanyúló hagyományokkal rendelkeznek a számos területre kiterjedő prevenciós stratégiáikat illetően, ennek következtében a rezisztenciaviszonyokat tekintve az egyik legkedvezőbb helyzetben vannak a kontinens országai között. Az antibiotikum-rezisztenciával szembeni hatékony munka sikeréhez nagyban hozzájárult az egészségügyi szektor szoros együttműködése helyi és országos szinten, illetve az államigazgatás és az állattenyésztési ágazat között. Ennek tudható be, hogy Svédországban a legalacsonyabb a haszonállatokhoz kapcsolódó antibiotikum-felhasználás, és már 1986-ban betiltották az antibiotikumok hozamfokozó szerként alkalmazását (az EU-ban ez 2006ban történt meg). Svédországban az első, antibiotikum-rezisztenciát közvetlenül megcélzó népegészségügyi programot 2000-ben tervezték és indították el, amely az országban már egy ideje múködő Strama nevű hálózaton alapult. Ez a szervezet 1995 óta országos szinten folytatott különböző tevékenységeket az antibiotikum-rezisztencia elleni küzdelemben. Az eredeti program kialakításának oka a 1990-es évek elején a penicillin-rezisztens Streptococcus pneumoniae izolátumok számának hirtelen emelkedése volt, amelyet Svédország déli részének gyermekpopulációjában figyeltek meg. A program kezdetben önkéntes alapon múködött, majd idővel a közigazgatási régiókban egyenként kialakult multidiszciplináris szakmai csoportok országos szinten kezdtek el dolgozni. A stratégiai program finanszírozása lépcsőzetes folyamat volt, a programban elért kezdeti sikereket és fejlesztéseket önkéntes munkával sikerült megvalósítani. A finanszírozás mértéke fokozatosan nőtt, majd állandóvá vált, jelenleg országos szinten kb. 2 millió euró, a helyi csoportok munkájára ezen felül további 3-5 millió euró áll rendelkezésre. Az évek során olyan magas színvonalon múködő szakmai közösséget hoztak létre, amelyet nemzetközileg is elismernek, mind a törvényhozás, mind a kutatás területén (ahol Svédország következetesen kiváló eredményeket ér el). Ez a stratégiai program egy átfogó célt és hét stratégiai célt definiál, amelyekben a svéd kormány meghatározta a célok eléréséhez szükséges létfontosságú tényezőket [1. táblázat]. Ez a stratégia kiegészíthető további (lokális) kezdeményezésekkel a különböző területekre és ágazatokra vonatkozóan.
A helyi multidiszciplináris csoportokkal való munka során a program keretein belül számos tanulságot szürtek le: a nemzeti terápiás irányelveknek tartalmaznia kell minden, egészségi állapotra vonatkozó diagnosztikus kritériumot, az antibiotikum-használattal kapcsolatos kockázat-haszon analízist, mind a beteg, mind a társadalom szempontjából, valamint a beteg állapotára és a kezelés újraértékelésére vonatkozó ajánlásokat. Ezen kívül meg kell könnyíteni az alapellátásra vonatkozó nemzeti irányelvek végrehajtását, és azokat minél egyszerübb terápiás algoritmusokká kell alakítani (pl. egyértelmű tanácsadás az egészségügyi szakembernek, hogy mikor írjon fel antibiotikumot, és mikor ne). Végezetül, fontos figyelemmel kísérni az kezelőorvosok antibiotikum-felírási szokásait mind az alapellátásban, mind a kórházakban: ezzel elősegíthetjük az értékelést és a felírási szokások fejlesztését. Az antibiotikum-felhasználás és a rezisztencia szintje Svédországban a legalacsonyabb (az EU vonatkozásában), úgy a humán, mint az állatgyógyászati felhasználás tekintetében. 1992 és 2016 között az alapellátásban és a járóbeteg-szakellátásban a felnőtt populáció számára felírt receptek 1000 före jutó száma 43\%-kal csökkent, míg 73\%-kal a 0-4 év közötti populációban. Ezzel együtt a terápiás ajánlásokhoz való adherencia is lassan növekedni kezdett, így a légúti infekciók kezelésére szánt antibiotikumok mennyisége is csökkent. Ezen kívül több indikációban volt eltolódás a széles spektrumú szerek irányából a célzott terápia felé az alapellátásban és a hospitalizált betegek esetén egyaránt, összhangban a nemzetközi ajánlásokkal. Az eredményes változások fontos tényezői: a járóbeteg-ellátásban felírandó receptszám célértékének meghatározása, a terápiás ajánlásokon alapuló minőségi indikátorok meghatározása és figyelembevétele, valamint a receptet felírók számára a lokális szintű visszajelzés biztosítása.

$\mathrm{Az}$ antibiotikum-rezisztencia már sok éve kiemelt fontosságú kutatási téma Svédországban. A legújabb kutatási és innovációs törvényjavaslat külön kitért az antibiotikumok és fertőző betegségek fontosságára, melynek eredményeképpen számos új kutatóintézet, doktori iskola alakult, és több kutatási pályázatot hirdettek meg a témában. Svédország - Olaszországgal együtt - 2010-ben további nemzetközi kutatási együttmúködés kezdeményezője volt az antibiotikum-rezisztencia területén: a 
Joint Programming Initiative on Antimicrobial Resistance (JPIAMR; melynek elnökségi funkcióját Svédország töltötte be 6 évig), amely számos ország antibiotikumokkal kapcsolatos politikáját határozta meg. A svéd állam és szakembereinek szerepvállalása a JPIAMR programban a jó példa terjesztésének fontosságáról tesz tanúbizonyságot. A svéd program nemzetközi folytatását az Egyesült Nemzetek Szövetsége (UN) által kiadott 2030-as Fenntartható fejlődés tervezete és a svéd kormány által kiadott Policy for Global Development-en belüli állásfoglalása teszi lehetővé.

Átfogó cél: A bakteriális fertőzések hatékony kezelésének biztositása emberekben és állatokban egyaránt.

\begin{tabular}{|c|c|c|}
\hline & Stratégiai célok & Stratégiai célok részletezve \\
\hline 1 & $\begin{array}{l}\text { Fokozott tudás fokozott } \\
\text { felügyelet révén }\end{array}$ & $\begin{array}{l}\text { - Az antibiotikum-rezisztenciára, az antibiotikum- és egyéb } \\
\text { antibakteriális szer fogyasztására vonatkozó adatokhoz való } \\
\text { hozzáférés biztosítása } \\
\text { - A környezeti antibiotikum-expozícióra vonatkozó adatokhoz való } \\
\text { hozzáférés biztosítása } \\
\text { - A különböző intézkedések eredményességének és költséghaté- } \\
\text { konyságának felmérése folyamatos adatgyűjtés segítségével }\end{array}$ \\
\hline 2 & $\begin{array}{l}\text { Folyamatos és szigorú } \\
\text { prevenciós tevékenységek }\end{array}$ & $\begin{array}{l}\text { - Megelőző intézkedések meghatározása és végrehajtása a } \\
\text { megfelelő ágazatokban, hogy a rezisztens kórokozók terjedését } \\
\text { leghamarabb észlelni tudják, elkerüljék vagy megakadályozzák } \\
\text { - A multirezisztens baktériumok terjedésének minimalizálása }\end{array}$ \\
\hline 3 & $\begin{array}{l}\text { Antibiotikumok felelős } \\
\text { használata }\end{array}$ & $\begin{array}{l}\text { - Az antibiotikumok és egyéb antibakteriális szerek ( } p l \text { fertőtlenítő- } \\
\text { szerek) használata és kezelése a legracionálisabb módon }\end{array}$ \\
\hline 4 & $\begin{array}{l}\text { Új módszerek megismerése és } \\
\text { felhasználása a fertőző } \\
\text { betegségek kezelésére és } \\
\text { antibiotikum-rezisztencia } \\
\text { megelőzésére }\end{array}$ & $\begin{array}{l}\text { - A bakteriális fertőzések mechanizmusával kapcsolatos alapvető } \\
\text { ismeretek fejlesztése, új diagnosztikai módszerek bevezetése, } \\
\text { védőoltások és új kezelési stratégiák fejlesztésének támogatása } \\
\text { - A bakteriális rezisztencia kialakulásával és terjedésével kapcsolatos } \\
\text { alapvető ismeretek fejlesztése, az új és meglévő antibiotikumok } \\
\text { alkalmazásának optimalizálása céljából }\end{array}$ \\
\hline 5 & $\begin{array}{l}\text { Az antibiotikumrezisztencia- } \\
\text { probléma megértésének } \\
\text { elősegítése és javítása a } \\
\text { társadalomban }\end{array}$ & $\begin{array}{l}\text { - A helytelen antibiotikum-felhasználásból adódó veszélyekkel } \\
\text { kapcsolatos vélekedés és kompetencia fejlesztése valamennyi } \\
\text { érintett fél (és a lakosság) körében, beleértve a fertőzések } \\
\text { megelőzésével kapcsolatos intézkedéseket }\end{array}$ \\
\hline 6 & $\begin{array}{l}\text { Infrastruktúra- és } \\
\text { rendszerfejlesztés }\end{array}$ & $\begin{array}{l}\text { - Az antibiotikum-rezisztenciával kapcsolatos munkavégzés } \\
\text { megfelelő stratégia alapján, hatékony és koherens módon, a } \\
\text { különböző érdekelt felek szerepkörének meghatározásával } \\
\text { - A tevékenységek nyomon követése, és stratégiamódosítás } \\
\text { a kapott eredmények alapján }\end{array}$ \\
\hline 7 & $\begin{array}{l}\text { Vezetői pozíció betöltése } \\
\text { az Európai Unión belül } \\
\text { és más nemzetközi } \\
\text { együttműködésekben }\end{array}$ & $\begin{array}{l}\text { - Svédország vezető szerepe az antibiotikumrezisztencia-ellenes } \\
\text { küzdelemben és a megfelelő antibiotikum-felhasználás elősegítés- } \\
\text { ében, mind országon belül, mind az EU szintjén és globális } \\
\text { kooperációban egyaránt } \\
\text { - } \quad \text { Kulcsfontosságú munka az Egyesült Nemzetek Szövetsége (UN) } \\
\text { 2030-as Fenntartható fejlődés tervezetén és a svéd kormány által } \\
\text { kiadott Policy for Global Development tervezetén belül }\end{array}$ \\
\hline
\end{tabular}




\section{TANULSÁGOK A HAZAI SZAKEMBEREK SZÁMÁRA}

Az antibiotikum-rezisztencia problémája minden nemzetet érintő, globális probléma. A Svédországban múködő rendszer remek példája annak, mikor a szakemberek országos szinten fontos probléma megoldásán kezdenek önerőből dolgozni, majd a programot nemzetközi sikerűvé emeli az állam közremúködése és támogatása. A Magyarországon kialakult rezisztenciaviszonyok közel sem olyan előnyösek, mint az északi országokban levők. A széles spektrumú szerek alkalmazása rendkívül magas arányú az alapellátásban csakúgy, mint a fekvőbetegek esetén, emellett az állatgyógyászatban/haszonállatok vonatkozásában használt antibiotikumok mennyisége 5-10-szerese az svéd átlagnak. Számos terület (infrastruktúrafejlesztés, infekciókontoll-intézkedések, lakossági ismeretek fejlesztése, kutatás) áll rendelkezésre, ahol a hazai egészségügyi szféra a lokális igényeknek és szükségleteknek megfelelően a svéd stratégiából integrálhatna elemeket. Kezdetnek mindenképp szükség lenne magyarországi felmérésre, hogy pontosan azonosítani tudjuk a nem megfelelő antibiotikum-felhasználás mozgatórugóit és a lehetséges beavatkozási pontokat.

\section{KÖSZÖNETNYILVÁNITÁS}

A közlemény létrejöttét az ESCMID Mentorprogram és az NTP-NFTÖ-18-C-0225 „Nemzet Fiatal Tehetségeiért Ösztöndij”" támogatta. 